\title{
The Concept Evolution and Form Expression of the Ewenki National Art Culture from the Perspective of Art Anthropology
}

\begin{abstract}
Guo Yang ${ }^{1, *}$
${ }^{1}$ Heihe University, Heihe, Heilongjiang 164300, China

*Corresponding author. Email: $12637694 @ q q . c o m$

ABSTRACT

The Ewenki nationality is one of the four small ethnic groups living on forest and hunting in the Heilongjiang River Valley with only language but no characters. The graphic image, as a kind of art culture, records the traditional production and life of the Ewenki nationality, and also shows the traditional aesthetic emotion and unique taste of the Ewenki nationality. Therefore, the art culture of graphic images is more important to the national cultural heritage of the Ewenki nationality. From the research perspective and method of art anthropology, this paper discusses the importance of the Ewenki national art culture, the concept evolution of the Ewenki national art culture, and the application and development of the form expression of the Ewenki national art culture, and then, it explains the influence of the Ewenki nationality's natural living environment, living habits and concepts on the Ewenki nationality art culture, and verifies the contemporary value of the Ewenki nationality art.
\end{abstract}

Keywords: Art anthropology, Ewenki nationality, Art culture, Concept evolution, Form expression.

\section{INTRODUCTION}

The Ewenki nationality is a northern minority with more than 10,000 people. The Ewenki nationality has very rich traditional arts, and the fine arts are not only affected by the living natural environment, but also by a certain degree of human regional culture. This paper mainly analyzes the influence of nature and human culture on Ewenki nationality art culture, and then verifies the origin and development of Ewenki nationality art. Since the Ewenki nationality is a nation with language but no characters, its ancient graphics and patterns record the production and life of the Ewenki nationality, and also show the Ewenki nationality's aesthetic emotions and its unique characteristics of art and culture. The art culture of graphic and

*Funds: This paper is the phased achievement of the basic scientific research operating expense research project of the provincial colleges and universities of the Heilongjiang Provincial Department of Education "Study on Forest and Hunting Nationality Plastic Arts Visualization from the Cultural Perspective of Heilong River Valley", Project Number: 2018KYYWF-1274. pattern design is more important to the national cultural heritage of the Ewenki nationality.

\section{THE IMPORTANCE OF STUDYING THE EWENKI NATIONALITY ART CULTURE}

The Ewenki nationality means people who live in the mountains. For this reason, when tracing the origin of the Ewenki nationality's fine arts culture, it's necessary to consider that they have been baptized over the years. The unique culture created by the Ewenki nationality is closely connected with the cultural connotation of nature. These unique cultures and unique artistic expressions make the Ewenki nationality's culture long-standing and well-established.

This paper serves as the phased achievement of the 2018 Heilongjiang Provincial Philosophy and Social Science Research Planning Project, the project "Study on the Inheritance and Development of the Plastic Arts of the Sauron Tribe in the Heilong River Valley of China and Russia", Project Number: 18YSE614. 
Most of the common houses and daily necessities among the Ewenki nationality have chosen some natural raw materials. These raw materials are simple and practical, and they are very simple, which can effectively decorate houses and can also show the unique characteristics of the nationality. The art culture of the Ewenki nationality is also mainly applied to clothing and daily necessities. Throughout the history of the Ewenki nationality, it can be found that most of its paintings are mostly totem symbols, animal silhouettes, or unique patterns of the nation, which are influenced by human nature and shaman culture.

From the beginning to the present, the changes in Ewenki nationality's lifestyle have also been impacted by foreign cultures. The foreign culture is not only the Central Plain Culture, but also the culture of other countries. Traditional culture and handicrafts are gradually on the verge of extinction in the younger generation. To this end, it is necessary to analyze the source of its culture, and do a good job in the inheritance of the culture, to be able to understand the unique beauty of art culture, and to demonstrate cultural and aesthetic functions. By analyzing the source of the Ewenki nationality's traditional art culture, people can also understand the positive impact these traditional art culture has brought to the Ewenki nationality's development, inheritance and daily life.

\section{THE CONCEPT EVOLUTION OF EWENKI NATIONALITY ART CULTURE}

The aesthetic emotions assumed by many patterns of the Ewenki nationality also record production, life, and unique culture and history. Throughout the history of the development of the Ewenki nationality, it can be found that various totems and cultures are involved. Through these totems and symbols of content form, it can be inferred that the Ewenki nationality's cognition of the world and the depiction of the world. And the Ewenki nationality's patterns have always been an identification with nature and shaman culture. It can be said that shaman culture is a part that can't be ignored by the Ewenki nationality, and it is also an important part of the cultural composition.

Through analyzing the Ewenki nationality art culture, people can also perceive that the shaman culture also has a certain influence on its art culture, but in real life, its art patterns are mostly colored and expressed in three different colors: blue, red and yellow, and these three different colors also represent three common contents in nature, among which blue corresponds to the sky, yellow corresponds to the earth, and red corresponds to flames. These patterns express the Ewenki nationality's awe of heaven and earth, nature and people themselves. However, in the later development of the Ewenki nationality, a large number of flowers and plants and animals patterns appeared. The stylized process of shaman culture and Ewenki nationality culture through exaggerated expressions reflects the unique aesthetic emotions of the nation and makes the art of the Ewenki nationality easier. In the analysis of the Ewenki nationality traditional art culture, this paper is going to analyze the influence of nature and human beings on the Ewenki nationality culture.

\subsection{Art Culture in the Natural Environment}

The art culture involved in the Ewenki nationality contains a series of viewpoints in nature. They believe in animism. Animism is a very broad term. The Ewenki people believe that every creature in nature has life and soul. In the art and culture of the Ewenki nationality, the sun god will be portrayed as a sun girl. The Ewenki people use poetry to sing the warmth and beauty brought by the sun god, while the moon god is portrayed as the moon goddess, praising its tranquility, bringing light to people, and at the same time making people feel comfortable. Every scene in the natural world of the Ewenki nationality, and common content in nature will be depicted in a unique way. They believe that every form in nature is worthy of respect and admiration, which is also the inseparable relationship between the origin of the Ewenki national art culture and nature. The Ewenki nationality believes that people can communicate with all things in nature to achieve the purpose of understanding the development direction of all things in nature. In their beliefs, people can communicate with nature to solve many problems. The art culture of the Ewenki nationality also represents a kind of mass culture, representing the foundation of the unity and struggle of the entire nation. What they pursue in art culture is the nobility and respect for nature, the desire for a rich life, the pursuit of their own strength, and the worship of their ancestors. This also makes it necessary to consider the traditional cultural connotation of the Ewenki people and the relationship between them and the natural world when analyzing the art culture of the Ewenki 
nationality. Especially when analyzing the paintings of the Ewenki people, many paintings are made with red pigments. Red itself is also highly subjective. It can be seen that among the Ewenki people, they are full of awe and dependence for red. They believe that red is related to life and has a very strong life consciousness. Not only that, red itself also has a striking and enthusiastic effect, which assists the Ewenki nationality in another perception of color and nature.

\subsection{Human Survival and Art Culture}

The fixed natural environment also makes humans need to continue to evolve, they need to adapt to the current natural environment in order to have stronger control capabilities, and they can also transform into their unique culture through nature. The particularity of the natural environment has also affected the living conditions of the Ewenki nationality. It is very difficult to transform the living conditions by transforming nature. Hunting and raising reindeer have become the main source of life for people living there, and they use white birches and animal skins to build houses similar to tents with the purpose of withstanding wind and rain, and resisting the severe cold. This is their way of life.

The Ewenki nationality is also a nomadic nation, and its ability to interfere with nature is relatively low. The daily necessities are directly processed and made from nature. Therefore, the Ewenki people are more willing to regard daily necessities and life products as a gift from nature. They have always had a very strong sense of lofty and awe for nature, which is also a part that can't be ignored in the production and life of the Ewenki nationality. The relationship between man and nature has always been irreconcilable, which is the initial recognition of primitive humans. With the gradual understanding of natural phenomena and the natural environment, people can perceive the impact of different organisms and vegetation on human development through experience, and perceive the world through their own senses, and they will have more understanding of nature. However, when a nation first appeared, they were afraid of nature, and they were very curious about nature. The same is true of the Ewenki nationality. They have an insurmountable gulf with nature. They are in awe of nature in their perception of nature, and they believe that people can't fully communicate with nature. For this reason, the Ewenki nationality began to pray for the gifts of nature, for good weather and safety for people and animals. Nature and humans are also opposed in some respects. For example, in a normal natural environment, beasts may threaten the existence of people, and in order to thrive, humans need to constantly fight against nature and against beasts. Humans and nature need a medium of communication. Under this stage, the art culture of the Ewenki nationality was also influenced by the shaman, which made the art culture of the Ewenki nationality more abundant.

\section{THE APPLICATION AND DEVELOPMENT OF EWENKI NATIONAL ART CULTURE FORM EXPRESSION}

\subsection{Birch Bark Art}

In order to explore the long history of Ewenki nationality art culture, it is also necessary to consider how the Ewenki nationality art culture is currently applied and what forms of expression it exhibits. The most expression of Ewenki nationality art culture is birch bark products.

For the Ewenki nationality, the birch bark was gradually reduced until the second half of the 20th century. For them, May and June are the best year to peel off the birch bark and the best season. In the process of processing birch bark, in order to make birch bark a good handicraft and improve the quality of application in daily life, Ewenki people need to process birch bark. There are three main processing methods: the first is to peel off the birch bark directly and then roast it with fire to soften the birch bark. Then the birch bark can be simply cut according to people's needs. For this method, it is necessary to consider that the sealing device needs watering when sewing to improve its overall application effect. The second is to boil the bark. The boiled bark can make the birch bark more flexible, and the boiled birch bark is taken out and dried. The third is to directly take the birch bark home and produce, but before producing, it firstly needs to dig a soil pit nearly $30 \mathrm{~cm}$ deep. And the next step is to bury the soil pit with about $116 \mathrm{~cm}$ thick half-dried horse dung, then put the birch bark in and bury it with about $10 \mathrm{~cm}$-thick soil. This method can make the birch bark soft and swell like animal skin, as various products of birch bark.

The common birch bark tent at this stage is the most traditional living form of the Ewenki nationality. Its overall shape is similar to a cone. It 
can also be called Tieha (铁哈) among the Ewenki nationality, which is a natural umbrella-shaped frame built from another 25 or 31 tree trunks, and three wooden poles with slits support it in the middle. In summer, the tent is wrapped by stitched birch bark slices, and each piece of birch bark is approximately $80 \mathrm{~cm}$ in length, and its length varies, and the longest can reach about $4 \mathrm{~m}$, which can be processed into very thin birch bark slices and cut into suitable size for application. It can also become a wide strip in the room, being folded around $2 \mathrm{~cm}$, and then stitched together. The tent built in this way can fully meet the needs of the Ewenki nationality during use, and can be disassembled anytime and anywhere. Birch bark boats are also one of the common means of transportation for the Ewenki nationality. The birch bark boat has a rectangle shape with a flat bottom and sharp arcs at both ends. The length of the bottom hull is generally about $3 \mathrm{~m}$, while the widest part of the hull can reach $80 \mathrm{~cm}$, and the maximum speed can reach about $60 \mathrm{~cm}$. The outside of the birch bark as the hull needs to be wrapped well. The hull made of birch bark is relatively new and very buoyant. The hull is streamlined, the resistance is very small when traveling, and the traveling speed is fast, which can meet the production needs of the Ewenki nationality when hunting in the water.

\subsection{Animal Skin Art}

In addition to utensils made from bark, there are also some animal skin products, and common animal skin products include clothing, boxes and storage bags. When analyzing storage bags, it can be found that there are many forms, such as chopstick bags, spoon bags, workbags and leather bags. In contrast, these small leather objects, no matter their shape or style, can show the artistic skills and culture of the Ewenki nationality. Taking rectangle leather bags as an example, the straps are chosen as decoration, which can make the whole storage bag look very lively and delicate. The decorative patterns are deformed in a curled shape, with antlers and symmetrical deer head patterns mostly, and a few curled butterfly patterns. Among them, the decoration of the antler patterns is very rich, followed by a large number of plant patterns and antler mending patterns.

\section{CONCLUSION}

In summary, the cultural inheritance of the Ewenki nationality is formed due to the development of its society and the development of the times. Throughout the art culture of the Ewenki nationality, in most cases, objects are depicted in the form of lines. Most of the handicrafts formed by art culture are expressed in lines and traditional patterns. This is the most important way for their nation to portray the world, and convey ideas and feelings. All along, what they see and hear has been classified and designed through symbolization. Not only that, the influence of religion is also involved in the inheritance of Ewenki nationality culture. For this reason, some art depicts the harmonious coexistence of man and nature or the graceful inheritance of natural objects.

\section{AUTHORS' CONTRIBUTIONS}

This paper is independently completed by Guo Yang.

\section{REFERENCES}

[1] Liu Zhongguo. A Study on the Fine Arts of the Aoluguya Ewenki Nationality in Northern Hunting Nationalities [J]. Journal of Institutes of HulunBuir, 2017-03. (in Chinese)

[2] Han Bo, Bi Mingyan. Research on the Cultural Expression Forms in Ethnic Tourism - Taking Nehe Xingwang Ewenki Customs Park as an Example [J]. Heilongjiang National Series, 2020(02):54-58. (in Chinese)

[3] Ha Liya. Research on the Technology of Birch Bark Products of Ewenki Nationality [D]. Inner Mongolia Normal University, 2007. (in Chinese)

[4] Wang Qiang. Loss and Exhaustion — A Study of Reindeer Ewenki Folk Art from the Perspective of Consumer Culture [D]. Northeast Normal University, 2017. (in Chinese)

[5] Suri Guga. A Study on the Historical Memory of the Ewenki Nationality in Tunguska Taking the Ewenki Sumu of Chenbalhu Banner as an Example [D]. Inner Mongolia University, 2020. (in Chinese)

[6] Han Xiaoying. Investigation and Research on Traditional Auspicious Patterns and Fur Craft of Ewenki Nationality [D]. Inner Mongolia Normal University, 2020. (in Chinese) 